\title{
The Effects of Nonylphenol on Bax and Caspase-3 Expressions in 3T3-L1 Preadipocytes and Adipose Tissue of Rats
}

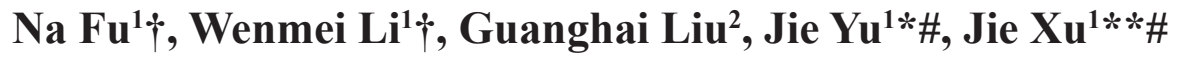 \\ ${ }^{1}$ School of Public Health, Zunyi Medical University, Zunyi, Guihzou \\ ${ }^{2}$ Morphological Laboratory, School of Basic Medicine, Zunyi Medical University, Zunyi, Guizhou
}

Received: 9 July 2020

Accepted: 6 November 2020

\begin{abstract}
The aim of this work was to examine the in vivo and in vitro effects of NP on Bax and Caspase-3 expressions in 3T3-L1 preadipocytes and adipose tissue of rats. Forty rats were gavaged with NP for 24 weeks at the doses of $0.02 \mu \mathrm{g} / \mathrm{kg}, 0.2 \mu \mathrm{g} / \mathrm{kg}, 2.00 \mu \mathrm{g} / \mathrm{kg}$ and groundnut oil, respectively. 3T3-L1 preadipocytes were exposed to NP $(0,40 \mathrm{pM}, 40 \mathrm{nM}, 40 \mu \mathrm{M})$ during the stages of the MDI-induced differentiation. The expression of apoptotic protein Bax and Casapse- 3 was both up-regulated in all NP treatment groups than that in the control. Oil Red O staining of 3T3-L1 preadipocytes exposed to $40 \mu \mathrm{M}$ NP showed that the whole field of view was the reddest, and new lipid droplets were observed. At the late stage of differentiation, the expression of Caspase-3 protein at high dose of NP group was higher than that of the control group. Simultaneously, the protein expression of Bax decreased at the late stage. Subchronic exposure of NP could increase the body weight and expression of Bax and Caspase-3 in adipose tissue of rats. The accumulation of lipid droplets and increased expression of Bax and Caspase-3 in 3T3-L1 preadipocytes after NP exposure were revealed as well.
\end{abstract}

Keywords: Nonylphenol, 3T3-L1 preadipocytes, Bax, Caspase-3

\section{Introduction}

In recent years, the number of obese people has increased year by year, which has become a global

$\uparrow \mathrm{Na} \mathrm{Fu}$ and Wenmei Li are co-first authors contributed equally to this paper.

\#Jie Xu and Jie Yu are co-corresponding authors who contributed equally to this study.

*e-mail: Xujie360@sina.com

**e-mail: 737717694@qq.com public health problem. China, the world's most populous country, has entered a period of rapid aging, the prevalence of metabolism syndrome among people aged $\geq 60$ years was $36.9 \%$ [1]. According to current research, endocrine-disrupting chemicals (EDCs) have become one of the main factors affecting obesity $[2,3]$. EDCs refer to exogenous chemical substances that interfere with the development and functions of endocrine systems. Nonylphenol (NP) has been introduced as the most common EDCs, which is ubiquitous in our daily life. NP is widely used in industrial production and home and lifestyle products such as detergents, moisturizers, preservatives, and 
some plastic products, etc. Previous studies have shown that NP could be detected in the air, water other than food $[4,5]$. Our prior study showed that the pollution of NP in Xiangjiang River, tap water, and aquatic in Zunyi of China belongs to moderate or severe level in the world [6]. Xie et al. reported the increase level of NP in the air of the North Sea of China [7]. NP exposure has toxic effects on reproductive, immune, endocrine and nerve systems. Xiao et al. [8] found that NP exposure could cause maternal reproductive toxicity during pregnancy, which was associated with the occurrence of spontaneous abortion. In addition, our previous study proved that NP exposure might have neurotoxic effects on brain, and induce depressive behavior in rats [9], however, the toxic effects of NP on apoptotisis related gene expression in adipocytes has never been elaborated, the relationship between NP and obesity is the focus of current research.

It has been confirmed that some EDCs (i.e. bisphenol A (BPA), Monoethylhexyl phthalate (MEHP)) can increase adipocyte apoptosis, which can lead to obesity [10, 11] . Previous studies of our research found that NP can lead to diabetes and obesity [12, 13, 9], etc. Apoptosis is a kind of programmed cell death. Bax and Caspase- 3 are important genes of apoptosis [14]. In vivo experiments, caspase activity and adipocyte apoptosis in adipose tissue of both obese mice and obese humans have been shown significantly increased [15]. Meanwhile, this study also reported that adipocyte apoptosis is a very critical progress in cell steatosis, which helps macrophages infiltrate adipose tissue, increase insulin secretion, and eventually contribute to cell steatosis; and then to inhibit adipocyte apoptosis may be a new strategy for treating metabolic complications associated with obesity [14, 15]. This study intends to determine for the first time the effects of subchronic NP exposure on body weight of rats and Bax and Caspase- 3 expression in adipose tissue through in vivo experiments, and then in vitro experiments to verify the effects of NP on apoptosisrelated proteins expression at different stages of 3T3-L preadipocytes differentiation, so as to provide clues and data basis for finding the etiology of obesity, diabetes and other metabolic syndromes caused by NP exposure.

\section{Materials and Methods}

\section{Chemicals and Reagents}

NP (purity $=98 \%$ ) was purchased from the Shandong Xiya Chemical Industry Co. LTD (Shandong, China). 3T3-L1 mouse embryonic fibroblast (No. ZQ0089) was purchased from the Shanghai Zhongqiao Xinzhou Biotechnology Co., Ltd. (Shanghai, China). BCA protein quantification kit was purchased from Beijing Solarbio Co., Ltd (Beijing, China). Trypsin was purchased from Sigma Chem Co. (St. Louis, MO, USA).
Anti-Caspase-3 rabbit monoclonal antibody and antiBax rabbit monoclonal antibody were purchased from Abcam (Cambridge, MA, USA). All other chemicals were commercially available.

Experimental Animal Grouping and Gavage

Forty 4-week-old healthy SD male rats $(150 \pm 10 \mathrm{~g})$, provided by the Daping Animal Center, Third Military Medical University [Certificate No. (SCXK (Chong) 2012-0005)], were housed under controlled 12/12 h light/dark cycle, natural ventilation, temperature $\left(22 \pm 2^{\circ} \mathrm{C}\right)$ and relative humidity $(60 \% \pm 5 \%)$ in animal rooms, and fed with pellet feed, free to eat and drink. The animals were randomly divided into 4 groups of 10 rats each: control group (group C, corn oil), and three groups exposed to NP with low, medium and high doses $(0.02,0.2,2.00 \mu \mathrm{g} / \mathrm{kg} \cdot$ day-1). All animals were garaged at a volume of $5 \mathrm{ml} / \mathrm{kg}$ for 24 weeks (168 days) at 8:00 am each day. The body weight of the rats was measured. After fasting and anesthesia, whole blood was taken through the abdominal aorta, the total blood volume of each rat was approximately $5 \mathrm{~mL}$. After serum was collected, it was stored at $-80^{\circ} \mathrm{C}$ for later use. Animal experiments were approved by the Zunyi Medical University ethics committee and all procedures were in stick accordance with the relevant regulations and requirements of the Zunyi Medical University.

The criteria for selecting the concentrations used: The admissible concentration of chronic NP exposure was $3.3 \mu \mathrm{g} / \mathrm{L}[16]$, and the LC50 (the concentration lethal to half of any given species over a certain time) for NP was $0.17 \mathrm{ng} / \mathrm{L}$ [17]. Additionally, the tolerance value of NP for mice was $0.17 \mu \mathrm{g} / \mathrm{L}$, which was reckoned and based on the safety factor (human:mice $=1: 100$ ). On account of principle that the lowest dose would be above the lower limit of the safe dose, therefore NP dose was set at the concentration of $0.02 \mu \mathrm{g} / \mathrm{kg} \cdot$ day- 1 , the other two doses would be10 times and 100 times concentration of 0.02 , hence the NP dose was $0.02,0.2$, $2 \mu \mathrm{g} / \mathrm{kg} \cdot$ day-1.

\section{Cell Culture, Staging and NP Exposure}

\section{Cell Culture and Passage}

3T3-L1 preadipocytes were maintained in phenol red-free Dulbecco's modified Eagle medium (DMEM; Invitrogen) supplemented with $10 \% \mathrm{FBS}$ in a $5 \% \mathrm{CO}_{2}$ incubator at $37^{\circ} \mathrm{C}$. Medium was changed every $48 \mathrm{~h}$, at the cell confluence up to $80 \%$, cells were digested by trypsin, centrifuged, and proceeded according to $1: 3$ to passage, or cell counting was performed and cells were seeded in cell plates. Cells was digested by trypsin, centrifuged to make a cell suspension with a cryopreserved solution, and placed the cryopreservation tube, and then stored in liquid nitrogen after gradient cooling. 


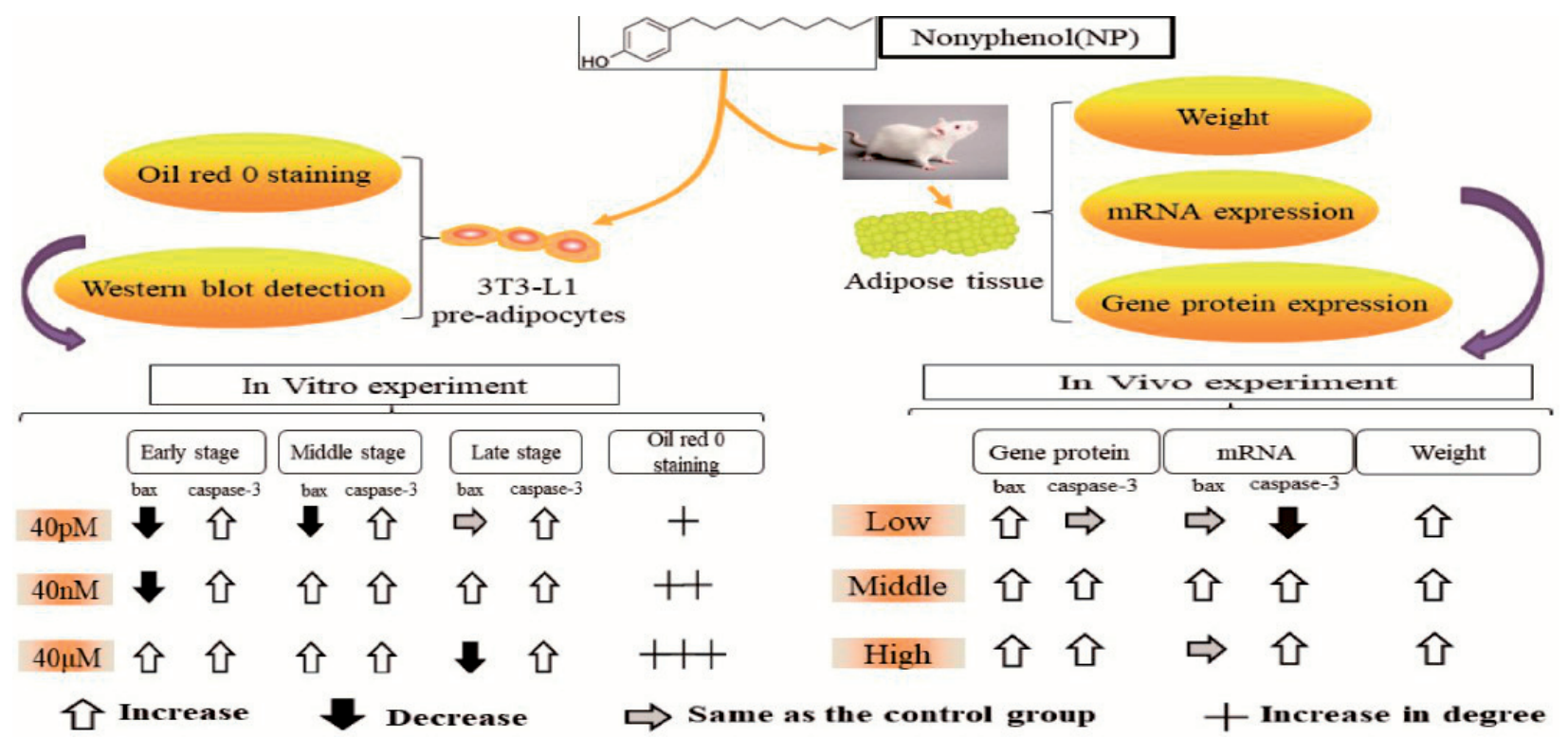

Fig. 1. Exposure protocols and time duration of exposure.

\section{Cell Induction and Differentiation}

3T3-L1 preadipocytes were induced into mature adipocytes under the MDI induction protocol [18]. MDI induction protocol is as follows: after the inhibition, cells were kept to $10 \%$ FBS medium and continued to culture for $48 \mathrm{~h}$, which is marked as 0 days and maintained in MDI induction medium [DMEM with $0.5 \mathrm{mM} 3$-isobutyl-1-methylxanthine (3-isobutyl-1methyl-7H-xanthine (IBMX), $1 \mu \mathrm{M}$ Dexamethasone (Dex), $0.1 \mu \mathrm{M}$ insulin (Insulin, I) in 10\% FBS] for $48 \mathrm{~h}$ (2 days), then exchanged to induction medium B $(0.1 \mu \mathrm{M}$ insulin in $10 \%$ FBS $)$ for $48 \mathrm{~h}$ (4 days), DMEM medium with $10 \% \mathrm{FBS}, 48 \mathrm{~h} /$ time for medium exchange, continued to culture until 12 days after induction until lipid droplets appeared in the cells.

\section{Staging and NP Exposing}

NP was exposed to 3T3-L1 differentiation, and doses were: $0,40 \mathrm{pM}, 40 \mathrm{nM}, 40 \mu \mathrm{M}$; the specific procedure was as followed: (1) in the early stage of induction, 3T3-L1 preadipocytes were exposed to NP working solution with DMEM for 48 hours after inhibition. (2) In the middle stage of induction: cells were treated with NP for $48 \mathrm{~h}$ in MDI induction medium as mentioned in materials 2.2. (3) In the later stage of induction, the cells were induced and differentiated by 2.2 procedure. Only on the $12^{\text {th }}$ day of, the cells were exposed to NP working solution for 48 hours. Cells were taken at each stage. Fig. 1 depicts exposure protocols and time duration of exposure.

\section{Extraction of Adipose Tissue}

After the rats were dissected, the para-gonadal fat pads were taken for gene expression assay, and the organ coefficient was calculated: the fat coefficient $=$ fat wet weight $(\mathrm{g}) /$ body weight $(\mathrm{g}) \times 100 \%$.

\section{Oil Red O Staining to Detect Intracellular Lipid Deposition}

Oil Red $O$ staining was performed on the differentiation stages induced by NP exposure to 3T3-L1 preadipocytes, and each stained slice was

Table 1 . The sequences of the primers.

\begin{tabular}{|c|c|}
\hline Gene name & Sequences \\
\hline \multirow{2}{*}{ Bax } & Forword:CAGGATGCGTCCACCAAGAA \\
\cline { 2 - 2 } & Reverse:CGTGTCCACGTCAGCAATCA \\
\hline \multirow{2}{*}{ Caspase-3 } & Forword:GGCCTGAAATACCAAGTGAGGAA \\
\cline { 2 - 2 } & Reverse:CCATGGCTTAGAATCACACACACA \\
\hline \multirow{2}{*}{$\beta$-actin } & Forword: CACCCGCGAGTACAACCTTC \\
\cline { 2 - 2 } & Reverse: CCCATACCCACCATCACACC \\
\hline
\end{tabular}




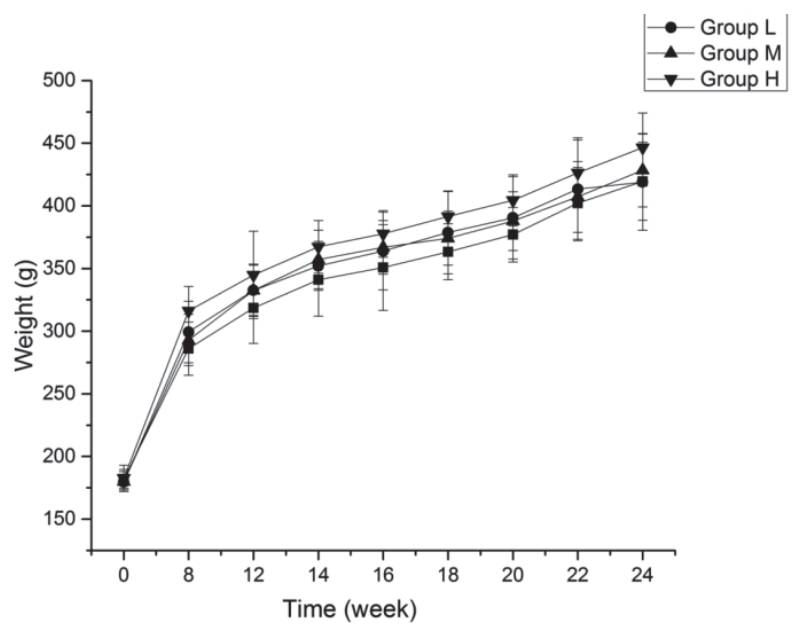

Fig. 2. Effect of NP exposure on body weight of rats $(n=10)$.

observed and photographed with intracellular lipid droplets under a $100 \times$ light microscope [19].

\section{Detection of Apoptosis Related Gene Expression in 3T3-L1 Preadipocytes}

Western Blot (WB) was performed to detect the protein expression of Bax and Caspase-3 in 3T3-L1 preadipocytes; RT-qPCR was assayed to detect expression of Bax and Caspase-3 mRNA in adipose tissues [20].

Total RNA was extracted from samples. cDNA synthesis from total RNA samples was performed with cDNA Reverse Transcription Kit. RT-qPCR was performed using a qPCR platform and SYBR
Green normalised with $\beta$-actin. Differences in gene expression between groups were calculated by the relative quantitative method. The calculation formula is: $\mathrm{Q}=2^{-\Delta \Delta \mathrm{Ct}}$, and the $\mathrm{Ct}$ of internal control was at the range of 18-25. The sequences of the primers used are listed in Table 1.

\section{Statistical Analysis}

SPSS software (v23.0; SPSS Inc., Chicago, IL, USA) was used to perform statistical analyses. All descriptive statistics for variables in this study are reported as mean \pm standard deviation. ANOVA was used for comparison between multiple groups. Differences within the group were compared by the LSD method to the control group. The test level was $\alpha=0.05$. Three replicates were performed for each concentration, and the experiment was repeated three times

\section{Results}

\section{Effect of NP Exposure on Body Weight of Rats}

During the 0-16 weeks of breeding, the body weight of the NP-exposed group showed up-regulated trend, but there was no statistical significance $(P>0.05)$. At the $18^{\text {th }}$ week, the rats weight increased $\left(\mathrm{F}_{18 \text { weeks }}=2.312\right.$, $P_{18 \text { weeks }}=0.035$ ); during the 18-24 weeks of breeding, the rats' weight increased significantly, as shown in the NP high-dose group $>$ medium-dose group $>$ low-dose group $>$ control group $(P<0.05$, Fig. 2).

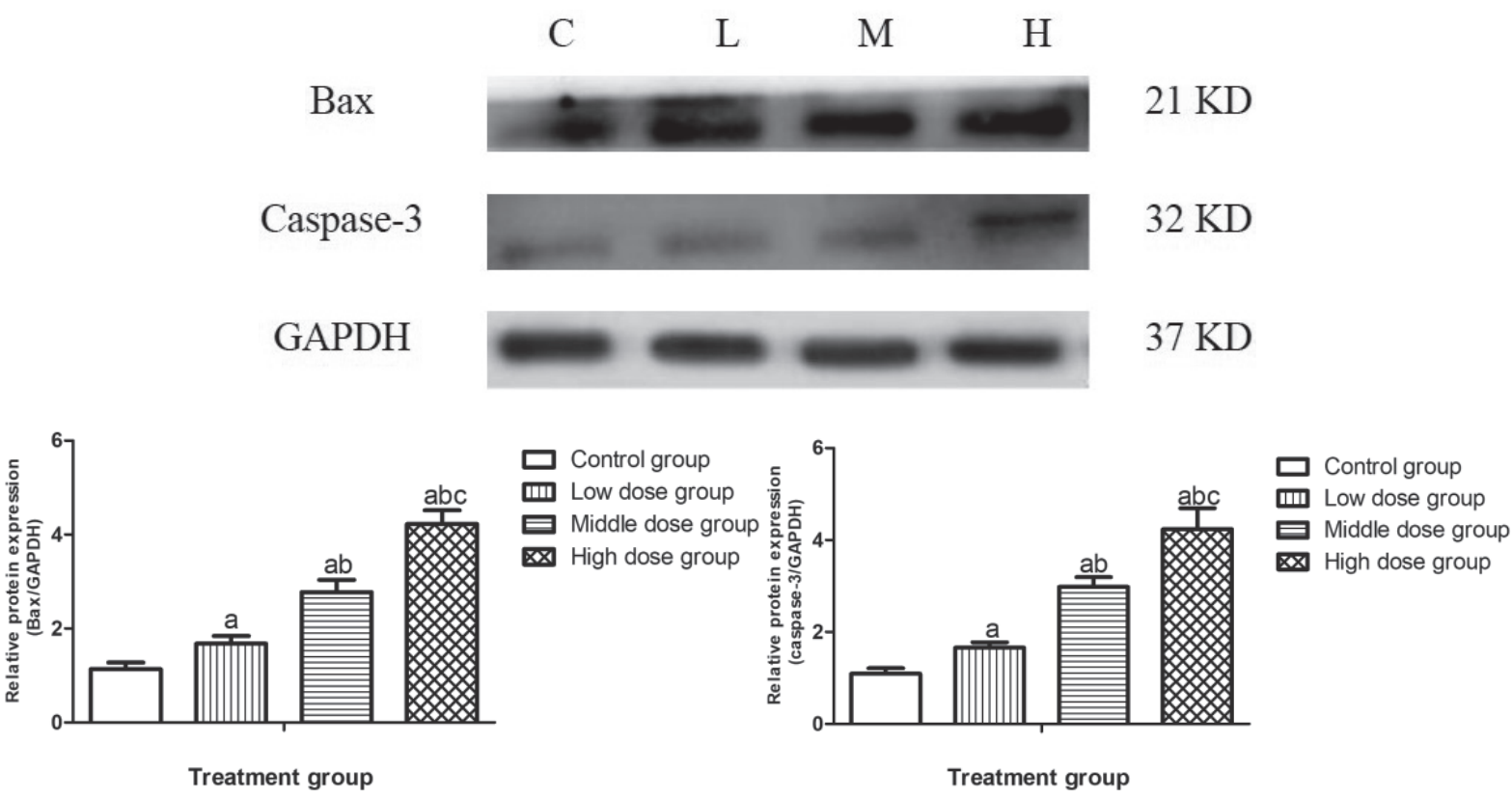

Fig. 3. Effect of NP exposure on the expression of apoptotic proteins (Bax, Caspase-3) in adipose tissue of rats ( $\mathrm{n}=10)$. C: control group; L: low dose group; M: medium dose group; H: high dose group. ${ }^{a} \mathrm{vs}$ control group, $\mathrm{P}<0.05$; ${ }^{\mathrm{b}} \mathrm{vs}$ low dose group, $\mathrm{P}<0.05$; ${ }^{\mathrm{c}} \mathrm{vs}$ high dose group, $\mathrm{P}<0.05$. 

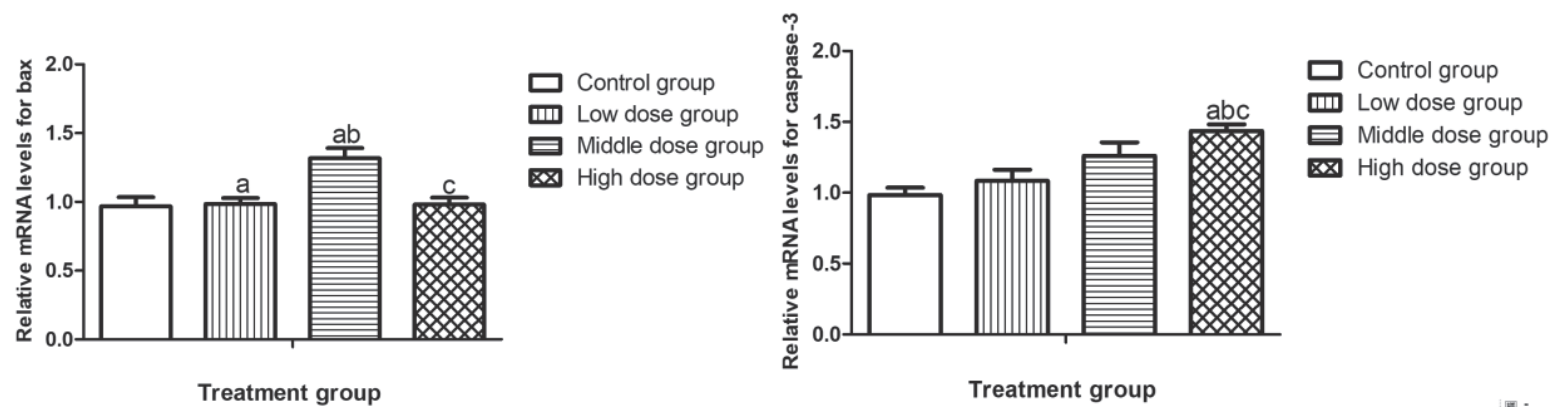

Fig. 4. Relative mRNA expression of apoptosis-related genes (Bax, Caspase-3) in adipose tissue of rats ( $\mathrm{n}=10)$. C: control group; L: low dose group; M: medium dose group; H: high dose group. ${ }^{a} \mathrm{vs}$ control group, $\mathrm{P}<0.05 ;{ }^{b} \mathrm{vs}$ low dose group, $\mathrm{P}<0.05$; ${ }^{\mathrm{c}} \mathrm{vs}$ high dose group, $\mathrm{P}<0.05$.

\section{Effect of NP Exposure on the Expression of Apoptotic Proteins (Bax, Caspase-3) in Adipose Tissue}

The expression of apoptotic protein Bax and Casapse-3 was both up-regulated in all the three NP exposure groups than in the control group. The expression of protein Bax was highest in group with high doses $\left(\mathrm{F}_{\mathrm{Bax}}=245.707, P<0.001\right)$; Meanwhile, the expression of protein Casapse-3 in high-dose group was around 3.5 fold of that of the control group. $\left(\mathrm{F}_{\text {Caspase-3 }}=87.711, P<0.001\right.$, Fig. 3).

\section{Effect of NP Exposure on mRNA Expression of Apoptosis-Related Genes (Bax, Caspase-3) in Adipose Tissue of Rats}

Compared with the control group, mRNA expression of Bax was significantly up-regulated in the NP medium-dose group $\left(\mathrm{F}_{\mathrm{Bax}}=31.758, P<0.001\right)$; expression of Caspsae-3 mRNA was significantly higher in the NP high-dose group than in the control group $\left(\mathrm{F}_{\text {Caspase-3 }}=42.238, P<0.001\right.$, Fig. 4$)$.

\section{Oil Red O Staining of 3T3-L1 Preadipocytes Exposed to NP}

After NP exposure to 3T3-L1 preadipocytes, no obvious Oil Red $\mathrm{O}$ staining was observed in the control group. When the NP concentration was $40 \mathrm{pM}$, the Oil Red O staining increased, which was deeper than that of the control group; when the NP concentration was $40 \mathrm{nM}$, the Oil Red O staining dramatically increased, it was deeper than the control group and NP concentration at $40 \mathrm{pM}$, and some cells appeared red. When the NP dose was $40 \mu \mathrm{M}$, the whole field of view was the reddest, and new lipid droplets were observed (Fig. 5).
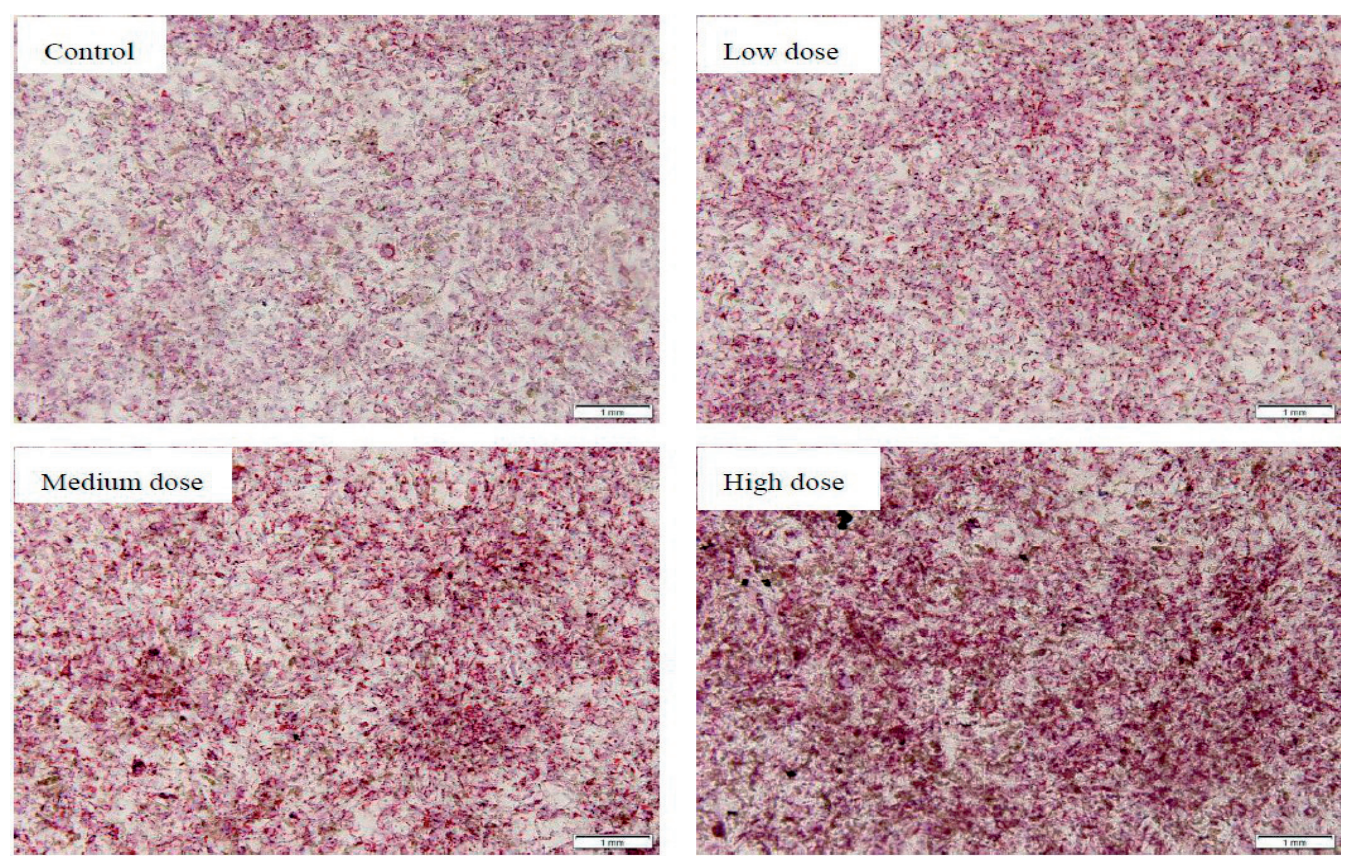

Fig. 5. Comparison of Oil Red O staining of T3-L1 cells exposed to different dose of NP $(100 \times)$. 
Effect of NP Exposure at the Early, Middle and Later Stages of Induction of 3T3-L1 Preadipocytes on Protein Expression of Bax and Caspase-3

At the early stage of induction, the relative protein expression of Bax in the high-dose NP exposure group was higher than that in the control group $\left(\mathrm{F}_{\text {Bax }}=220.050, P<0.001\right)$; and the relative protein expression of caspase-3 in all three NP exposed groups was higher than in the control group $\left(\mathrm{F}_{\text {Caspase-3 }}=1199.542, P<0.001\right)$. At the middle stage of induction, the relative protein expression of both Bax and Caspase-3 in high-dose exposed group was higher than that in the control group $\left(\mathrm{F}_{\mathrm{Bax}}=54.329\right.$; $\left.\mathrm{F}_{\text {Caspase-3 }}=449.201, P<0.001\right)$. At the late stage of differentiation, the expression of Caspase-3 protein at high dose of NP group was higher than that of the control group $\left(\mathrm{F}_{\text {Caspase-3 }}=15.490, P<0.001\right)$. However, Caspase-3 expression level was relatively lower than in the early and middle stages. Simultaneously, the protein expression of Bax also decreased at the late stage $\left(\mathrm{F}_{\text {Bax }}=4.686, P=0.008\right.$, Fig. 6$)$.

\section{Discussion}

In the current study, the potential toxic influence of nonylphenol on Bax and Caspase-3 expressions in 3T3-L1 preadipocytes and adipose tissue of rats was explored. The results of this study showed that subchronic exposure of NP could increase the body weight and expression of Bax and Caspase- 3 in adipose tissue of rats. In vitro, the accumulation of lipid droplets and increased expression of Bax and Caspase- 3 in 3T3-L1 preadipocytes after NP exposure were also revealed.

The results of this experiment confirmed that the subchronic exposure of NP could increase the body weight of rats, and the more NP exposed $(0-40 \mu \mathrm{M})$, the more body weight of rats gained. The experimental results verified the previous results of the research group [21], which was also reported by Zhang [22] and other scholars, that were: NP exposure contributed to the weight increase of rats offspring. Wang [23] et al. found that the possible mechanism of EDCs induced obesity is to directly combine with estrogen receptor

Early stage of induction
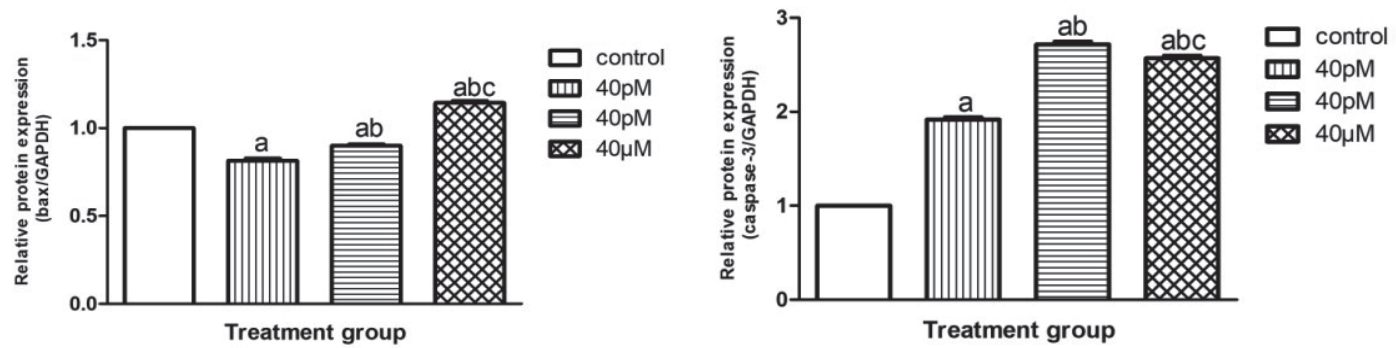

Middle stage of induction
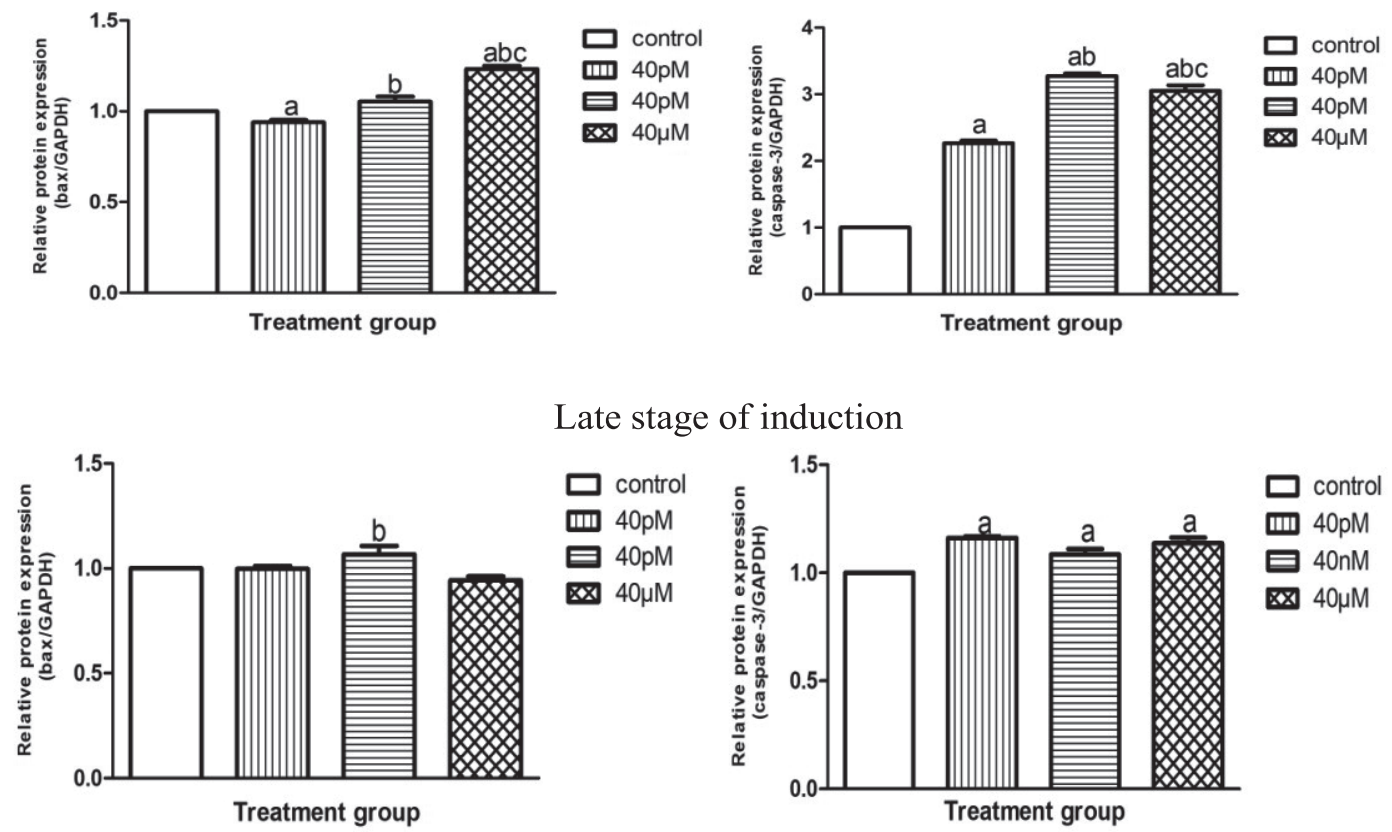

Late stage of induction
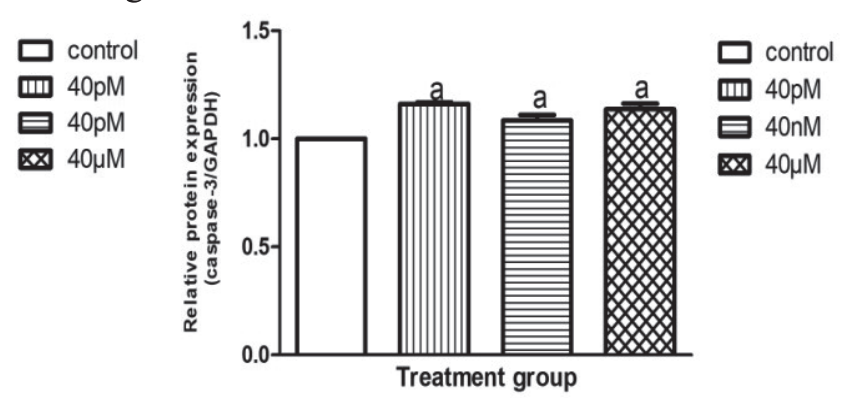

Fig. 6. Effect of NP exposure on apoptotic proteins (Bax, Caspase-3) at the early, middle and later stages of induction of 3T3-L1 preadipocytes. ${ }^{\mathrm{a}} \mathrm{vs}$ control group, $\mathrm{P}<0.05 ;{ }^{\mathrm{b}} \mathrm{vs}$ low dose group, $\mathrm{P}<0.05 ;{ }^{\mathrm{c}} \mathrm{vs}$ high dose group, $\mathrm{P}<0.05$. 
which plays the role of agonist or antagonist, and finally promotes the increase of rat's volume; NP can also be directly used as an active feeding metabolite to regulate rat's satiety, disturb lipid metabolism, and induce the increase of rat's weight [24]. In this study, NP exposure could lead to the increase expression of Bax and Caspase-3 in adipose tissue. Bax and Caspase family are important related genes in eukaryotic cell apoptosis. Many studies have confirmed that activated caspase-3 has the apoptotic effect [25-27]. The results showed that NP could increase the body weight, the expression of Bax and Caspase- 3 in rats, and there was a positive correlation between them, but it could not explain the causal relationship, further experiments are needed to explore their relationship.

The results of in vivo and in vitro experiments are the consistent: after NP exposure to 3T3-L1 preadipocytes, it was observed the increase of degree of Oil Red O staining with the increase of NP dosage, which indicated that the accumulation of lipid droplets in 3T3-L1 preadipocytes may be the cause of obesity; meanwhile, the up-regulation of protein expression of Bax and Caspase-3 in each NP exposure groups was found in the early and middle stage of NP induced 3T3-L1 preadipocytes. The above findings demonstrate that NP could increase the expression of Bax and Caspase-3, thus affecting the process of apoptosis in rats. Peng et al. [28] found that NP could affect the spermatogenic function of spermatogenic cells by increasing the expression of Bax and Caspase- 3 in rat testis. At present, there is no study on the increase of apoptosis of adipocytes induced by NP exposure. This study was the first to find that Bax and Caspase-3 expression of adipocytes of NP exposure to 3T3-L1 was mainly concentrated in the early and middle stage of induction, and the effect of the late stage of induction was not obvious. The early and middle stage of cell differentiation was the key stage of cell differentiation, which indicated that NP had an important impact on apoptosis of adipocytes in the early stage of cell formation. Although a large number of studies have reported that NP can affect the proliferation and differentiation of preadipocytes, few reports point to the critical stage of preadipocyte differentiation. If the proliferation and differentiation of adipocytes are interfered by chemical or physical methods in critical period, which could be a strategy to reduce the incidence of obesity-related diseases.

\section{Conclusion}

The subchronic exposure of NP could increase the weight of rats and the expression of Bax and Caspase- 3 in adipose tissue. In vitro, it was also found that the expression of Bax and Caspase-3 in preadipocytes increased after NP exposure, but further experiments are necessary to confirm whether there is a causal relationship between them. As mentioned earlier, adipose cell apoptosis is a very critical part of cell steatosis, which can induce fat degeneration of cell. Therefore, inhibition of adipocyte apoptosis can be used as one of the strategies for treating obesity-related metabolic complications.

\section{Acknowledgements}

This work was supported by the National Natural Science Foundation of China (81760580); the Key Program of Scientific and Technological Fund of Department of Science and Technology of Guizhou Province, China (2019-1466; 2018-1429); the Scientific and Technological Talent Support Program of the Educational Commission of Guizhou Province of China (KY[2018]054); the Excellent Youth Science and Technique Talents of Guizhou Province [2017]5612; 15851 Project Talent in Zunyi municipal government, Guizhou Province (2017, 2018(E-262)). Guizhou HighLevel Innovative Talent Support Program ([2020]6014).

\section{Availability of Data and Materials}

The datasets used and/or analyzed during the current study available from the corresponding author on reasonable request.

\section{Contributions}

Jie $\mathrm{Xu}$ and Jie $\mathrm{Yu}$ designed the study. $\mathrm{Na} \mathrm{Fu}$, Wenmei Li and Guanghai Liu analyzed and interpreted the data. Wenmei Li conducted the laboratory work. Wenmei Li, Jie Xu participated in the sample collection. Jie $\mathrm{Yu}$ and $\mathrm{Na} \mathrm{Fu}$ wrote the manuscript, Jie $\mathrm{Xu}$ revised the manuscript. All the authors read and approved this paper.

\section{Conflict of Interest}

The authors declare no conflict of interest.

\section{References}

1. HUIMIN Y., MEI Z., XIAO Z., YUNTING X., TAO S., ZHENPING Z., ZHIHUA C., ZHENGJING H., LIMIN W. Study of epidemiological characteristics of metabolic syndrome and influencing factors in elderly people in China. Chinese Journal of Epidemiology, 40 (3), 284, 2019.

2. BANSAL A., HENAO-MEJIA J., SIMMONS R.A. Immune System: An Emerging Player in Mediating Effects of Endocrine Disruptors on Metabolic Health. Endocrinology, 159 (1), 32, 2018.

3. PETRAKIS D., VASSILOPOULOU L., MAMOULAKIS C, PSYCHARAKIS C.,ANIFANTAKI A., Endocrine 
Disruptors Leading to Obesity and Related Diseases. Int J Environ Res Public Health. 14 (10), 1282, 2017.

4. PARK H., KIM K. Urinary Levels of 4-Nonylphenol and 4-t-Octylphenol in a Representative Sample of the Korean Adult Population. International journal of environmental research and public health, 14 (8), 2017.

5. LIN H.C., LI H.Y., WU Y.T., TSAI Y.L., CHUANG C.Y., LIN C.H., CHEN W.Y. Bayesian inference of nonylphenol exposure for assessing human dietary risk. The Science of the total environment, 713, 136710, 2020.

6. JIE Y., JIE Z., YA L., XUESONG Y., JING Y., YU Y., JIAQI Y., JIE X. Pollution by Nonylphenol in river, tap water, and aquatic in an acid rain-plagued city in southwest China. International journal of environmental health research, 27 (3), 179, 2017.

7. XIE Z., LAKASCHUS S., EBINGHAUS R., CABA A., RUCK W. Atmospheric concentrations and airsea exchanges of nonylphenol, tertiary octylphenol and nonylphenol monoethoxylate in the North Sea. Environmental pollution, 142 (1), 170, 2006.

8. CHEN X., CHEN M., XU B., TANG R., HAN X., QIN Y., XU B., HANG B., MAO Z., HUO W., XIA Y., XU Z., WANG X. Parental phenols exposure and spontaneous abortion in Chinese population residing in the middle and lower reaches of the Yangtze River. Chemosphere, 93 (2), 217, 2013.

9. YU J., XU W., LUO Y., OU W., LI S., CHEN X., XU J. Dynamic monitoring of depressive behavior induced by nonylphenol and its effect on synaptic plasticity in rats. The Science of the total environment, 689, 1012, 2019.

10. LENGYINZHI, LIYINGPEI, LUOSHIMENG, JIANGJIANHUA, ZHUQIXING, SHENTONG Effect of bisphenol A on 3T3-L1 preadipocyte differentiation in mice. Journal of Anhui Medical University, 51 (9), 1281, 2016.

11. XU W., YU J., LI S., XU J. Depressive behavior induced by nonylphenol and its effect on the expression of ER- $\alpha$ and ER- $\beta$ in nerve cells of rats. Journal of affective disorders, 263, 373, 2020.

12. YU J., XU W., LUO Y., OU W., LI S., CHEN X., XU J. Dynamic monitoring of depressive behavior induced by nonylphenol and its effect on synaptic plasticity in rats. The Science of the total environment, 689, 1012, 2019.

13. YU J., YANG J., LUO Y., MENGXUE Y., WENMEI L., YANG Y, LITING H., Xu J. The adverse effects of chronic low-dose exposure to nonylphenol on type 2 diabetes mellitus in high sucrose-high fat diet-treated rats. Islets, $\mathbf{1 0}$ (1), 1,2018 .

14. SJ.MARTIN Caspases: Executioners of Apoptosis. Pathobiology of Hunman Disease, 6 (8), 145, 2014.

15. ALKHOURI N., GORNICKA A., BERK M.P., THAPALIYA S., DIXON L.J., KASHYAP S., SCHAUER P.R., FELDSTEIN A.E. Adipocyte apoptosis, a link between obesity, insulin resistance, and hepatic steatosis. The Journal of biological chemistry, 285 (5), 3428, 2010.

16. BROOKE L., THURSBY G. Ambient aquatic life water quality criteria for nonylphenol. Washington DC, USA: Report for the United States EPA. Office of Water, Office of Science and Technology, , 2005.

17. WU Y., CHEN C., ZHOU Q., LI Q.X., YUAN Y., TONG Y., WANG H., ZHOU X., SUN Y., SHENG X. Polyamidoamine dendrimer decorated nanoparticles as an adsorbent for magnetic solid-phase extraction of tetrabromobisphenol $\mathrm{A}$ and 4-nonylphenol from environmental water samples. Journal of colloid and interface science, 539, 361, 2019.

18. ZIZOLA C.F., JULIANELLI V., BERTOLESI G., YANAGISHITA M., CALVO J.C. Role of versican and hyaluronan in the differentiation of 3T3-L1 cells into preadipocytes and mature adipocytes. Matrix biology: journal of the International Society for Matrix Biology, 26 (6), 419, 2007.

19. TAKETANI Y., YAMAGISHI R., FUJISHIRO T., IGARASHI M., SAKATA R., AIHARA M. Activation of the prostanoid FP receptor inhibits adipogenesis leading to deepening of the upper eyelid sulcus in prostaglandinassociated periorbitopathy. Investigative ophthalmology \& visual science, 55 (3), 1269, 2014.

20. ZOU B., GE Z., ZHU W., XU Z., LI C. Persimmon tannin represses $3 \mathrm{~T} 3-\mathrm{L} 1$ preadipocyte differentiation via upregulating expression of miR-27 and down-regulating expression of peroxisome proliferator-activated receptor- $\gamma$ in the early phase of adipogenesis. European journal of nutrition, 54 (8), 1333, 2015.

21. WENMEI L.I., JIE Y.U., YA L., PAN W., XUESONG Y., JING Y., JIE X.U. Effect of NP exposure on neonatal rat obesity of pregnant rats induced by high-fat and highglucose diet during perinatal period. Shandong Medical Journal, 57 (14), 18, 2017.

22. HONGYU Z., ZHIGUO L., XIAOYU K.E. Effect of perinatal exposure to 4-nonylphenol on adipogenesis in offspring rats. Chinese Journal of Public Health, 34 (2), 249, 2019

23. QIANG W., YU C., JIAO, YUEPING Z., HUI Z., YIRUI W.U., LING Z., RONGZHU L.U. Research advances in association of bisphenol A exposure with lipid metabolism and obesity. Chinese Journal of Pharmacology and Toxicology, (4), 632, 2014.

24. YU J., LI W.M., TANG L., LUO Y., XU J. In vivo and in vitro effects of chronical exposure to nonylphenol on lipid metabolism. Environmental sciences Europe, 32 (1), $2,2020$.

25. ROGERS C., FERNANDES-ALNEMRI T., MAYES L., ALNEMRI D., CINGOLANI G., ALNEMRI E.S. Cleavage of DFNA5 by caspase-3 during apoptosis mediates progression to secondary necrotic/pyroptotic cell death. Nature communications, 8, 14128, 2017.

26. FORNARI F., POLLUTRI D., PATRIZI C., LA BELLA T., MARINELLI S., CASADEI GARDINI A., MARISI G., BARON TOALDO M., BAGLIONI M., SALVATORE V., CALLEGARI E., BALDASSARRE M., GALASSI M., GIOVANNINI C., CESCON M., RAVAIOLI M., NEGRINI M., BOLONDI L., GRAMANTIERI L. In Hepatocellular Carcinoma miR-221 Modulates Sorafenib Resistance through Inhibition of Caspase-3-Mediated Apoptosis. Clinical cancer research : an official journal of the American Association for Cancer Research, 23 (14), 3953, 2017.

27. CHO S.O., LIM J.W., KIM H. Oxidative stress induces apoptosis via calpain- and caspase-3-mediated cleavage of ATM in pancreatic acinar cells. Free radical research, (3), $1,2019$.

28. DUAN P., HU C., BUTLER H.J., QUAN C., CHEN W., HUANG W., TANG S., ZHOU W., YUAN M., SHI Y., MARTIN F.L., YANG K. Effects of 4-nonylphenol on spermatogenesis and induction of testicular apoptosis through oxidative stress-related pathways. Reproductive toxicology, 62, 27, 2016. 